\title{
Ekonomik küreselleşme ve işgücü özgürlüğü kapsamında genç işsizliği: Dinamik panel veri analizi
}

\section{Youth unemployment in the context of economic globalization and labour freedom: Dynamic panel data analysis}

\author{
Emrullah Mete ${ }^{1}$
}

${ }^{1}$ Dr. Öğr. Üyesi, Giresun Üniversitesi Görele Uygulamalı Bilimler Yüksekokulu, Giresun, Türkiye, mtemrullah@gmail.com ORCID: 0000-0003-2240-9248

Başvuru/Submitted: 15/06/2021

Revizyon/Revised: 2/09/2021

Kabul/Accepted: 11/09/2021

Yayın/Online Published: 25/09/2021

Atıf/Citation: Mete, E., Ekonomik küreselleşme ve işgücü özgürlüğü kapsamında genç işsizliği: Dinamik panel veri analizi, bmij (2021) 9 (3): 1012-1020 doi:

https://doi.org/10.15295/bmij.v9i3.1868

\section{Öz}

İşsizlik sorunu uzun yıllardır tüm ekonomileri ilgilendiren önemli bir sorun olmuştur. Bu sorunun en çok etkilediği kesim ise sosyal ve psikolojik nedenlerden dolayı genç nüfus olmuştur. Genç işsizliği gelişmiş ve gelişmekte olan tüm ülkelerin sadece ekonomik anlamda değil aynı zamanda sosyal boyutta bir sorundur. Ülkeler hem genel işsizlik hem de genç işsizlik sorununu çözmek ve toplum refahını artırmak için sürekli politika geliştirmek zorunda kalmaktadır. Bu çalışmada ekonomik büyüme, ekonomik küreselleşme, işgücü özgürlüğü, ücret düzeyi ve sabit sermaye oluşumunun genç işsizliği üzerindeki etkisi araştırılmıştır. Analizde OECD üyesi 35 ülkenin 2005-2018 dönemine ait verileri kullanılmıştır. Yöntem olarak dinamik panel veri yöntemi kapsamında genelleştirilmiş momentler metodu (GMM) tahmincisinden yararlanılmıştır. Analiz sonuçlarına göre ekonomik büyüme, ekonomik küreselleşme ve sabit sermaye oluşumunun genç işsizliğini negatif yönlü etkilediği tespit edilmiştir.

Anahtar Kelimeler: Genç İşsizliği, Ekonomik Büyüme, Ekonomik Küreselleşme, İşgücü Özgürlüğü, Dinamik Panel Veri Analizi

Jel Kodlar1: F66, J64, O47

\begin{abstract}
The unemployment issue has been a significant problem that concerns all economies for many years. This issue mainly affected the young population because of social and psychological reasons. Youth unemployment is a problem in all developed and developing countries, not only in economic terms but also in the social dimension. Therefore, countries must constantly develop policies to solve the general unemployment and youth unemployment problem and increase society's welfare. This study investigated the effects of economic growth, economic globalization, labour freedom, wage level, and fixed capital formation on youth unemployment. In the analysis, data from 35 OECD member countries for the period 2005-2018 were used. As a method, a generalized method of moments (GMM) estimator was used within the scope of the dynamic panel data method. According to the analysis results, it has been determined that economic growth, economic globalization and fixed capital formation negatively affect youth unemployment.
\end{abstract}

Keywords: Youth Unemployment, Economic Growth, Economic Globalization, Labor Freedom, Dynamic Panel Data Analysis

Jel Codes: F66, J64, O47 


\section{Extended Abstract} Youth unemployment in the context of economic globalization and labour freedom: Dynamic panel
data analysis

\section{Literature}

Research subject

The phenomenon of unemployment is accepted as a global problem that comes first among the macroeconomic targets of all countries. The level of employment, which is one of the most critical indicators of societies' welfare level and economic development, obliges countries to take measures and develop policies. Unemployment, which expresses the situation that labour supply and demand are not equalized in the current period, and the economic system, or the labour force in employment is less than the total labour force, is a phenomenon that brings with it not only economic but also psycho-social and political problems (Üzar and Akyaz1, 2018: 464). Another dimension of unemployment is unemployment within the scope of the population between the ages of 15-24, which is defined as the young population by many international organizations, especially the International Labor Organization (ILO). It is accepted that youth unemployment, which refers to the inability of the so-called dynamic population to be included in the production process, poses a greater risk and problem for countries (Acedanski, 2016: 248). Youth unemployment is a social problem with potentially serious consequences such as delinquency, increasing the risk conditions of mature unemployment, leading to future income losses and increasing the risk of physical and mental illness. For these reasons, countries constantly monitor the unemployment situation and take measures to maintain the welfare level of society and maintain economic development.

Research purpose and importance

In this study, the effects of economic growth, economic globalization, labour freedom, fixed capital formation and wage level on youth unemployment in 35 OECD member countries were investigated from 2005 to 2018.

\section{Contribution of the article to the literature}

The study contributes to the literature as few studies examine the effects of economic globalization and labour freedom on youth unemployment.

\section{Design and method}

Research type

Research Article

\section{Research problems}

The research question was determined as "Do economic growth, economic globalization, labour freedom, wage level and gross fixed capital formation affect youth unemployment?"

\section{Data collection method}

The data set from WDI, OECD, KOF and The Heritage Foundations

Quantitative/qualitative analysis

A generalized method of moments (GMM) estimator was used within the scope of the dynamic panel data method.

\section{Research model}

This research model is determined as follows;

$$
\operatorname{yun}_{i t}=\alpha_{t}+\beta_{1} \operatorname{Lyun}_{(i t-1)}+\beta_{2} \operatorname{Lgdp}_{i t}+\beta_{3} \text { Lgfcf }_{i t}+\beta_{4} \text { lbrfree }_{i t}+\beta_{3} \text { ecgi }_{i t}+\beta_{3} \text { Lwage }_{i t}+u_{i t}(4)
$$

Findings and discussion

According to the model's results using resistant estimators, while the effect of economic growth, economic globalization, fixed capital formation on youth unemployment is statistically significant, labour freedom and wage levels on youth unemployment are not statistically significant. Thus, the analysis results show that the relationship between economic growth, economic globalization, fixed capital formation, and youth unemployment is negative. Again, when the analysis results are evaluated quantitatively, it shows that a 1 unit increase in economic growth, fixed capital formation and economic globalization level will cause a decrease of 0.01 units, 0.32 units and 0.008 units in youth unemployment, respectively. When the results of the analysis are evaluated in terms of economic growth, they confirm Okun's Law and overlap with the results of the studies of D'lppolito (2011), Güney and Cin (2020), Soylu and Aydın (2020) in the literature. In addition, the analysis results in terms of economic globalization overlap with the results of Awad (2019) and Awad and Youssof (2016).

\section{Conclusion, recommendation and limitations}

In this study, the effects of economic growth, economic globalization, labour freedom, fixed capital formation and wage level on youth unemployment were investigated in the light of the policies and regulations applied by the countries. Within the scope of dynamic panel data analysis, the GMM estimator was used in the study, and the data of 35 OECD member countries for the period 2005-2018 were used. The analysis results confirm Okun's Law and show that the increase in economic growth reduces youth unemployment. Likewise, the increase in fixed capital formation also reduces youth unemployment. There was no statistically significant relationship between wage level and labour freedom and youth unemployment in the mentioned period. Finally, the results of the analysis show that the increase in economic globalization reduces youth unemployment. This result indicates that the removal of barriers to the international movement of capital in the relevant country group and period reduces youth unemployment. The fact that youth unemployment is a significant problem in terms of economic and social consequences pushes countries to develop additional policies. When evaluated in this context, it seems essential for policymakers to use monetary and fiscal policies that increase economic growth. In addition, policies and regulations to increase international capital mobility in financial and real markets will positively impact employment by creating expansions in the manufacturing industry and providing financing. 


\section{Giriş}

İşsizlik olgusu tüm ülkelerin makro ekonomik hedeflerinin başında gelen uluslararası bir sorun olarak kabul edilmektedir. Toplumların refah seviyelerinin ve ekonomik kalkınmalarının en önemli göstergelerinden biri olan istihdam seviyesi, ülkeleri önlemler almaya ve politikalar geliştirmeye zorunlu kilmaktadır.

Mevcut dönem ve ekonomik sistem içerisinde emek arzı ile talebinin eşitlenmemesi ya da istihdamdaki işgücünün toplam işgücünden az olması durumunu ifade eden işsizlik, sadece ekonomik olarak değil aynı zamanda psiko-sosyal ve politik sorunları da beraberinde getiren bir olgudur (Üzar ve Akyazı, 2018: 464). Yeni iş imkanlarının oluşturulmasına kıyasla genel nüfusta meydana gelen artış işsizliği çoğu ekonomide fenomen haline getirmiştir. İşi olmayanların ekonomik ve mali sisteme yük olması, yaşanan hayal kırıklığı ve kişisel sorunların getirdiği kötü alışkanlıklar ve işsizliğin uzun vadeli olması durumunda işgücü piyasasında rekabet gücünün azalması hususları işsizliğin olumsuz sonuçları olarak kendini göstermektedir (Kaslik, Neamtu ve Vesa, 2021, s. 535).

Yaşam standartlarındaki yükselme ve buna ek olarak sanayileşmede, kadının işgücüne katılımında ve işgücünün niteliğinde yaşanan gelişmelere karşı iş imkanlarının yetersiz kalması işsizlik sorununu daha da sorunlu hale getirmektedir. Bu sebeplerden dolayı ülkeler toplumun refah düzeyini korumak ve ekonomik kalkınmayı sürdürmek için işsizlik durumunu sürekli takip etmekte ve önlemler almaktadır.

İşsizlik sorununa çözüm noktasında ülkelerin ekonomik büyümeyi artırma çabaları gelmektedir. Ekonomik büyümenin işsizliği direkt olarak etkilediği yani azalttığı hususu Okun (1962) tarafından ortaya konulmuş Okun Yasası'na dayanan genel bir görüştür. Ampirik literatürde Okun Yasası'nı doğrulayan oldukça geniş bir alanın oluşması, ekonomik büyümeyi artırıcı faktörlerin aynı zamanda işsizliği azaltacağı düşüncesini beraberinde getirmiştir. İşsizliğin belirleyicileri ve azaltıcı faktörlerle ilgili ampirik literatürde genel olarak doğrudan yabancı yatırımlar, ihracat, ithalat, kamu harcamaları gibi faktörlerin kullanıldığı görülmektedir.

Ekonomik küreselleşmeyle birlikte ekonomik ve siyasi engellerin kalkması üretimin ve/veya sermayenin işgücünün yoğun olduğu ülkelere hareket edebilmesini sağlamıştır. Ayrıca ülke veya ekonomik entegrasyon içindeki ülke gruplarında işgücü özgürlüğünün gelişmesi işgücünün hareketliliğ̆i sağlamaktadır. Makro ekonomik faktörlerin yanında ekonomik küreselleşme ve işgücü özgürlügünün artırılması ülke ve ülke grupları açısından farklılık arz etse de işsizliğe çözüm politikaları kapsamında önem taşımaktadır.

İşsizliğin bir başka boyutu ise başta Uluslararası Çalışma Örgütü (ILO) olmak üzere birçok uluslararası örgüt tarafından genç nüfus olarak tabir edilen 15-24 yaş aralığındaki nüfus kapsamındaki işsizliktir. Dinamik nüfus olarak tabir edilen kesimin üretim sürecine dahil olamamasını ifade eden genç işsizliğinin ülkeler açısından daha büyük risk ve sorun teşkil ettiği kabul edilmektedir (Acedanski, 2016: 248). Genç işsizliği potansiyel olarak suça meyil etme, olgun işsizliğinin risk koşullarını artırma, gelecekteki gelir kayıplarına yol açma ve fiziksel ve ruhsal hastalık riskini artırma gibi ciddi sonuçları olabilecek sosyal bir sorundur. Ayrıca genç işsizliğinin genel işsizlikten farklı olarak kendine has nedenleri vardır. Verimlilikleri ve niteliklerinin belirsiz olması işverenler açısından olumsuz durum teşkil etmektedir. Motivasyon eksikliği ve kırılgan yapıya sahip olmaları gibi psikolojik faktörler yine genç işsizliğinin kendine has nedenlerini oluşturmaktadır (Hallsten, Edling ve Rydgren., 2017, s. 234). Ayrıca, genç nüfusun kariyer planlaması yaparken plansız veya gerçeklerden uzak planlar yapması, eğitimli ve donanımlı olmalarına karşılık piyasadaki iş gücü talebi ile karşılıklı uyumun sağlanamaması genç işsizliğinin ortaya çıkmasına ve/veya artmasına neden olabilmektedir (Yıldız, 2019: 21).

Bu çalışmada OECD üyesi 35 ülkede ekonomik büyüme, ekonomik küreselleşme, işgücü özgürlügüu, sabit sermaye oluşumu ve ücret düzeyinin genç işsizliği üzerindeki etkisi 2005-2018 dönemi için araştırılmıştır. Çalışmada dinamik panel veri yöntemi uygulanmıştır. Çalışma, ekonomik küreselleşme ve işgücü özgürlüğünün genç işsizliği üzerindeki etkisini inceleyen çalışmaların az olması nedeniyle literatüre katkı yapmaktadır.

Bu kapsamda giriş bölümünden sonra çalışmanın ikinci bölümünde literatür taramasına yer verilmiş, üçüncü bölümde veri seti yöntem tanıtılmıştır. Dördüncü bölümde analiz sonuçları yer almaktadır. Beşinci ve son bölümde ise sonuç ve değerlendirme kısmıla çalışma tamamlanmıştır.

\section{Literatür taramas1}

Genel itibariyle tüm ülkelerde mevcut olması nedeniyle genç işsizliği üzere yapılan çalışmalar ekonomi literatüründe oldukça fazla sayıda yer almaktadır. Ülke ve ülke grupları, dönemler ve genç işsizliğini 
etkileyebilecek faktörlere göre değişiklik arz eden çalışmalar farklı ampirik analizler çerçevesinde halihazırda ekonomi literatürüne katkı yapmaya devam etmektedir.

Choudhry, Marelli ve Signorelli (2010) ekonomik kalkınmanın farklı seviyelerindeki 72 ülke için finansal krizlerin genç işsizliği üzerindeki etkisini incelemişlerdir. 1980-2005 dönemi verilerinin kullanıldığı analizde Arellano Bond GMM tahmincisinden yararlanılmıştır. Analiz sonuçları finansal krizlerin genç işsizliğini artırdığını göstermektedir.

D'lppolito (2011) Danimarka ve İtalya için ekonomik ve finansal faktörlerin genç işsizliği üzerindeki etkilerini incelemişlerdir. 1990-2010 dönemi verilerinin kullanıldığı çalışmada resgresyon ve eş bütünleşme testlerinden yararlanılmıştır. Regresyon sonuçları ekonomik büyümenin genç işsizliğini azalttığı; enflasyon ve faiz oranlarının genç işsizliği üzerindeki etkisinin istatistiksel olarak anlamsız olduğu; eş bütünleşme sonuçları Danimarka' da faiz oranları ile genç işsizliğinin eş bütünleşik olduğunu ortaya koymaktadır.

Caporale ve Gil-Alane (2014) genç işsizliğin belirleyicilerini 15 Avrupa ülkesi kapsamında değerlendirmişlerdir. 1980-2005 dönemi verilerinden yararlanılarak panel eş bütünleşme analizinin kullanıldığı çalışma sonuçlarına göre ekonomik büyüme ve enflasyonun genç işsizliği ile uzun dönemde eş bütünleşik olduğu tespit edilmiştir.

Sam (2015) genç işsizliğin belirleyicilerini Kenya için araştırmıştır. 1979-2012 dönemi verilerinin kullanıldığı çalışmada ARDL sınır testi yaklaşımından yararlanılmıştır. Analiz sonuçlarına göre nüfus, ekonomik büyüme, doğrudan yabancı yatırımlar ve dış borçların söz konusu dönemde genç işsizliğin belirleyicilerin olduğu tespit edilmiştir.

Sertkaya ve Okur (2016) genç işsizliğin belirleyicilerini Türkiye için değerlendirmişlerdir. 1988-2014 dönemi verilerinin kullanıldığı çalışmada nedensellik analizinden yararlanılmıştır. Analiz sonuçları ekonomik büyüme, enflasyon ve yükseköğretim okullaşma oranının genç işsizliğin nedeni olduğunu ortaya koymaktadır.

Awad ve Youssof (2016) ekonomik küreselleşmenin işsizlik üzerine etkisini Malezya için değerlendirmişlerdir. 1980-2014 dönemine ait verilerin kullanıldığı çalışmada ARDL sınır tesi yaklaşımından yararlanılmıştır. Analiz sonuçları ekonomik küreselleşmedeki artışın uzun dönemde işsizliği azalta noktasında pozitif etkiye sahip olduğunu göstermektedir.

Sönmez ve Özerkek (2018) genç işsizliğinin belirleyicileri konusunda Türkiye'yi İstatistiki bölge sınıflandırmasına göre 26 alt bölge için incelemişlerdir. 2004-2013 dönemine ilişkin verilerin kullanıldığ1 analizde dinamik panel veri yönteminden yararlanılmıştır. Analiz sonuçları, ekonomik büyüme ve dışa açıklığın genç işsizliği üzerinde anlamlı bir etkisi tespit edilemezken enflasyon ve göreli kohort büyüklüğünün genç işsizliği üzerinde anlamlı etkisi olduğunu göstermektedir.

Awad (2019) ekonomik küreselleşmenin genç işsizliği üzerine etkisini 50 Afrika ülkesi için araştırmıştır. 1994-2013 dönemi verileri kullanılarak Arellano Bond GMM tahmincisinden yararlanılan çalışmada analiz sonuçları ekonomik küreselleşmenin genç işsizliği azalttığı, iş gücü piyasası düzenlemeleri ve dışa açıklığın genç işsizliğini azalttığını göstermektedir.

Balcı İzgi ve Konu (2019) genç işsizliğinin belirleyicileri için BRICS ülkeleri ve Türkiye'yi 1997-2017 dönemi verileriyle incelemişlerdir. Panel ARDL yöntemini kullandıkları çalışmanın analiz sonuçları söz konusu dönem ve ülke grubunda nüfus artış oranı ve tüketim harcamalarındaki artışın erkek genç işsizliğini istatistiksel olarak anlamlı ve negatif yönlü etkilediğini göstermektedir.

Kanberoğlu ve Göçer (2019) genç işsizliğini inovasyonla değerlendirmiştir. Türkiye'de patent sayıları, ar-ge yatırımları, teknolojiye dayalı ithalat ve ihracatın genç işsizliğine etkisinin incelendiği çalışmada nedensellik analizinden yararlanılmıştır. 1995-2017 dönemine ait verilerle gerçekleştirilen analiz sonuçlarına göre teknolojiye dayalı ithalatın genç işsizliğinin nedeni olduğu tespit edilmiştir. Patent sayılarıyla genç işsizliği arasında nedensellik ilişkisine rastlanılmamıştır.

Güvenoğlu ve Bayır (2020) genç işsizliğini etkileyen faktörleri gelişmiş ve gelişmekte olan 55 ülke için değerlendirmişlerdir. 2002-2019 dönemine ilişkin verilerden yararlanılan analizde panel regresyon yöntemi kullanılmıştır. Analiz sonuçları, nüfus, yatırım ve doğrudan yabancı yatırımların genç işsizliği üzerinde anlamlı etkisinin olmadığını; enflasyon, ekonomik büyüme ve kamu harcamalarında meydana gelecek artışın genç işsizliğini azalttığını; dışa açıklığın ise gen işsizliği artırdığını göstermektedir.

Polat (2020) ekonomik ve politik belirsizliklerin Yunanistan' daki genç işsizliğine etkisini araştırmıştır. 1998-2019 yılları arası dönemin çeyrek yıl verileriyle analiz edildiği çalışmada ARDL sınır testi yaklaşımından yararlanılmıştır. Analiz sonuçlarına göre ekonomik ve politik belirsizliklerin genç 
işsizliğini artıran en önemli faktör olduğu; ekonomik büyüme ile genç işsizliğin ters yönlü hareket ettiği ve kısa dönemde faiz oranlarının genç işsizliğini arttırdığı tespit edilmiştir.

Soylu ve Aydın (2020) genç işsizliğin gelişim ve belirleyicileri kapsamında Avrupa Birliği ülkeleri ile Türkiye' yi değerlendirmişlerdir. 2000-2018 dönemi verilerini kullanarak en küçük kareler yönteminden yararlanılan çalışmada Türkiye verileriyle analiz yapılmıştır. Analiz sonuçları gençlerin işgücüne katılım oranlarındaki artışın genç işsizliğini artırdığını; enflasyon ile genç işsizliği arasında ters yönlü ilişki olduğunu; ekonomik büyüme, doğrudan yabancı yatırımlar ve eğitim harcamalarındaki artışın genç işsizliği azalttı̆̆ını göstermektedir.

Güney ve Cin (2020) genç işsizliğin ve genel işsizliğgin belirleyicilerini Avrupa Birliği ülkeleri ve Türkiye için 1991-2016 döneminde incelemişlerdir. Panel regresyon analizinin kullanıldığı analiz sonuçları ekonomik büyüme, doğrudan yabancı yatırımlar ve enflasyonun hem genç hem de genel işsizlikle istatistiksel olarak anlamlı ve negatif ilişki içinde olduğunu; finansal kriz verilerinin ise genç ve genel işsizliği pozitif yönlü etkilediğini ve genç işsizliğin söz konusu belirleyici değişkenlerden genel işsizliğe göre daha fazla etkilendiğini göstermektedir.

\section{Veri seti ve yöntem}

Çalışmada OECD üyesi 35 ülkede (Avusturalya, Şili, Çekya, Estonya, Finlandiya, Macaristan, İzlanda, İsrail, Japonya, Güney Kore, Litvanya, Letonya, Lüksemburg, Meksika, Yeni Zelanda, Portekiz, Slovakya, Slovenya, ABD, Avusturya, Kanada, Fransa, Hollanda, Almanya, İtalya, İngiltere, Belçika, Danimarka, İrlanda, Yunanistan, İsviçre, İsveç, İspanya, Norveç, Portekiz) ekonomik büyüme, ekonomik küreselleşme, işgücü özgürlüğü, sabit sermaye yatırımı ve ücret düzeylerinin genç işsizliği üzerindeki etkisi araştırılmıştır. 2005-2018 yılları arası dönemin ele alındığı çalışmada analizde kullanılan değişkenlere ilişkin bilgiler Tablo 1'de yer almaktadır. Tablo 1'de yer alan değişkenlere ilişkin veriler veri tabanlarından elde edildiği için etik kurul onay belgesi gerekmemektedir.

Tablo 1: Veri Seti

\begin{tabular}{llll}
\hline Değişken kodu & Değişken adı & Açıklama & Kaynak \\
\hline Lyun & Genç işsizliği & $15-24$ yaş arası toplam işgücünün yüzdesi & WDI \\
\hline Lgfcf & Gayri safi sabit sermaye oluşumu & Sabit 2010 US\$ & WDI \\
\hline lbrfree & İşgücü özgürlüğ̈̈ & Endeks değeri & Heritage \\
& & & Foundation \\
\hline ecgi & Ekonomik küreselleşme & Endeks değeri & KOF \\
\hline Lwage & Ücret & Sabit 2019 fiyatları US\$ & OECD \\
\hline Lgdp & GSYH & Yıllık \% değişim & WDI \\
\hline
\end{tabular}

Tablo 1'de yer alan değişkenlerden yararlanılarak çalışmada panel veri analizi kapsamında dinamik panel veri modeli kullanılmıştır. Dinamik panel veri modelleri, bağımsız değişkenin gecikmeli değerinin de bağımsız değişken olarak ilave edildiği dağıtılmış gecikmeli ve bağımlı değişkenin gecikmeli değerinin bağımsız değişken olarak ilave edildiği otoregresif modeller olarak iki kısma ayrilmaktadır.

Genç işsizliğini etkileyen faktörlerin etki düzeyinin incelendiği bu çalışmada genelleştirilmiş momentler metodu (GMM) kullanılmıştır. Arellano Bond tarafından geliştirilen ve birim (N) boyutunun zaman $(\mathrm{T})$ boyutundan büyük olduğu durumlarda uygulanabilmektedir. Bu yöntemde araç değişken matrisi yardımı ile birinci fark modeline dönüştürülmekte, dönüştürülen model genelleştirilmiş en küçük kareler yöntemiyle tahmin edilmektedir (Tatoğlu, 2013: 65). Dinamik panel veri modeli Denklem 1'de gösterilmektedir.

$Y_{i t}=\delta Y_{i, t-1}+\beta^{\prime} x_{i t}+u_{i t} i=1, \ldots, N ; t=1, \ldots, T$

Denklem 1'de $\delta$ scaler terimi, $x_{t t}^{\prime} 1 \times K$ ve $\beta, K \times 1$ boyutlarındaki matrisleri ifade etmekte, $u_{i t}{ }^{\prime}$ nin ise tek yönlü hata bileşen modelini izlediği varsayılmaktadır (Baltagi, 2005: 135).

İki aşamalı bir tahminci olan GMM tahmincisinin tutarlılı̆̆ı iki temel varsayıma dayanmaktadır. İlki araç değişkenlerinin geçerliliği ikincisi ise otokorelasyon varsayımlarıdır. Araç değişkenlerinin geçerliliği Sargan testi ile otokorelasyon ise birinci farklar modelinden elde edilen kalıntıları kullanan ve Arellano Bond (1991) tarafından geliştirilen (AR1) ve (AR2) testleri kullanılmaktadır (Akbulut Yıldız, 2020, s. 108).

Genelleştirilmiş momentler tahmincisinde (GMM) birinci fark dönüşümü birim etkiyi modelden düşürmektedir. Ayrıca bağımlı değişkenin bir gecikmeli değeri modelde kullanılan diğer bağımsız değişkenler ile birlikte modele bağımsız değişken olarak yeniden eklenmektedir (Tatoğlu, 2013, s. 65). 
Modelde aşırı tanımlama kısıtlamalarının geçerliliği Sargan testi ile kontrol edilmektedir (Arellano ve Bond, 1991, s. 283).

$m=\Delta \hat{v} W\left(\sum_{i=1}^{N} W_{i}^{\prime} \Delta \widehat{(v)}_{i}(\widehat{v})_{i}^{\prime} W_{i}\right)^{-1} W^{\prime} \Delta \hat{u} \sim \chi_{p-K-1}^{2}$

Birinci farklar modelinde birinci mertebeden otokorelasyon olması $\mathrm{E}\left(\mathrm{v}_{\mathrm{itt}} \mathrm{v}_{\mathrm{i}(\mathrm{t}-1)}\right)=0$ önemli değildir. GMM tahmincisinin etkin olması için ikinci mertebeden otokorelasyon olmaması $\left(E\left(v_{i t} v_{i t-2}\right)=0\right.$ gerekmektedir. Arellona ve Bond (1991) okorelasyonu test etmek için birinci farklar modelinden elde edilen kalıntıları kullanmaktadır. Arellano Bond'un geliştirdiği test istatistiği aşağıdaki şekilde gösterilebilir.

$m_{2}=\frac{\hat{v}_{-2} \hat{v}}{\hat{v}^{\frac{1}{2}}} \tilde{a} N(0,1)$

Arellano Bond'un GMM yaklaşımına göre oluşturulan model Denklem 4'te yer almaktadır.

$$
\operatorname{yun}_{i t}=\alpha_{t}+\beta_{1} \operatorname{Lyun}_{(i t-1)}+\beta_{2} L g d p_{i t}+\beta_{3} L g f c f_{i t}+\beta_{4} \text { lbrfree }_{i t}+\beta_{3} \text { ecgi }_{i t}+\beta_{3} \text { Lwage }_{i t}+u_{i t}
$$

\section{Analiz sonuçları}

Çalışmada 2005-2018 döneminde OECD üyesi 35 ülkede ekonomik büyüme, ekonomik küreselleşme, işgücü özgürlüğü, sabit sermaye yatırımı ve ücret düzeylerinin genç işsizliği üzerindeki etkisi GMM tahmincisi ile analiz edilmiştir. Analize ilişkin bulgular Tablo 2' de yer almaktadır.

Tablo 2'de yer alan GMM tahmincisi sonuçlarına üzere, bağımlı değişkenin gecikmeli değerinin bağımsız değişken olarak modele eklendiği ve genç işsizliği üzerinde etkisini açıklamada istatistiksel olarak anlamlı olduğu görülmektedir. Modelin anlamlı olduğu ise Wald testi sonuçlarına göre teyit edilmektedir. Otokorelasyonun varlığı ve araç değişkenlerinin geçerliliği şeklinde iki temel varsayıma dayalı olan GMM tahmincisinin tutarlılığı Arellano Bond'un otokorelasyon testi ve sargan testi ile gerçekleştirilmiştir.

Otokorelasyon testi sonuçları birinci mertebeden otokorelasyon olduğu ancak ikinci mertebeden otokorelasyonun olmadığı tespit edilmiştir. Teoride belirtildiği üzere modelin tutarlılığının şartı ikinci mertebeden otokorelasyonun olmamasıdır. Araç değişkenlerinin geçerliliği konusunda yapılan sargan testi sonuçlarına göre araç değişkenlerinin geçerli olduğu tespit edilmiştir. Modelin tahmininde GMM iki aşamalı standart hatalar sapmalı olduğundan dolayı model dirençli tahminciler (Windmeijer Standart Hatalar) ile test edilmiştir.

Dirençli standart hataların kullanılması standart hata değerlerinde değişime neden olmuştur. Otokorelasyon testi sonuçları birinci mertebeden otokorelasyonun varlığını, ikinci mertebeden otokorelasyonun olmadığını göstermektedir. Dirençli hataların kullanıldığı modelde sargan testi yani araç değişkenlerinin geçerliliği testi yapılmamaktadır. 
Tablo 2: GMM Tahmincisi Analiz Sonuçları

\begin{tabular}{|c|c|c|c|}
\hline \multicolumn{4}{|l|}{ Bağımlı Değişken: Lyun } \\
\hline Bağımsız Değişkenler & Katsayı & Test istatistiği & P-Olasılık Değeri \\
\hline Lyun (1) & 0.7175 & 36.30 & 0.000 \\
\hline Lgdp & -0.0111 & -53.05 & 0.000 \\
\hline Lgfcf & -0.3272 & -12.88 & 0.000 \\
\hline lbrfree & -0.0009 & -4.07 & 0.000 \\
\hline ecgi & -0.0082 & -9.29 & 0.000 \\
\hline Lwage & -0.1519 & -2.02 & 0.043 \\
\hline \multicolumn{2}{|c|}{ Model için Gerekli Diğer Testler } & Test istatistiği & P-Olasılık Değeri \\
\hline \multicolumn{2}{|l|}{ Wald Testi $\left(\chi^{2}\right)$} & 15893.86 & 0.0000 \\
\hline \multicolumn{2}{|c|}{ Arellano-Bond Otokorelasyon Testi AR(1) } & -3.1182 & 0.0018 \\
\hline \multicolumn{2}{|c|}{ Arellano-Bond Otokorelasyon Testi AR(2) } & -0.7967 & 0.4256 \\
\hline \multicolumn{2}{|l|}{ Sargan Testi } & 31.8819 & 1.000 \\
\hline \multicolumn{4}{|c|}{ Dirençli Tahminciler ile Modelin Testi (Windmeijer Standart Hatalar ile) } \\
\hline \multicolumn{4}{|l|}{ Bağımlı Değişken: Lyun } \\
\hline Bağımsız Değişkenler & Katsayı & Test istatistiği & P-Olasılık Değeri \\
\hline Lyun (1) & 0.7175 & 10.64 & 0.000 \\
\hline Lgdp & -0.0111 & -5.93 & 0.000 \\
\hline Lgfcf & -0.3272 & -2.92 & 0.003 \\
\hline lbrfree & -0.0009 & -1.23 & 0.218 \\
\hline ecgi & -0.0082 & -2.64 & 0.008 \\
\hline Lwage & -0.1519 & -0.68 & 0.498 \\
\hline \multicolumn{2}{|c|}{ Model için Gerekli Diğer Testler } & Test istatistiği & P-Olasılık Değeri \\
\hline \multicolumn{2}{|l|}{ Wald Testi $\left(\chi^{2}\right)$} & 512.83 & 0.0000 \\
\hline \multicolumn{2}{|c|}{ Arellano-Bond Otokorelasyon Testi AR(1) } & -2.9618 & 0.0031 \\
\hline \multicolumn{2}{|c|}{ Arellano-Bond Otokorelasyon Testi AR(2) } & -0.7918 & 0.4284 \\
\hline
\end{tabular}

Dirençli tahmincilerin kullanıldı̆̆ı model sonuçlarına göre ekonomik büyüme, ekonomik küreselleşme, sabit sermaye oluşumunun genç işsizliği üzerindeki etkisi istatistiksel olarak anlamlı iken, işgücü özgürlüğü ve ücret düzeylerinin genç işsizliği üzerindeki etkisi istatistiksel olarak anlamlı olmadiğı görülmektedir. Analiz sonuçları, ekonomik büyüme, ekonomik küreselleşme ve sabit sermaye oluşumu ile genç işsizliği arasındaki ilişkinin negatif yönlü olduğunu göstermektedir. Yine analiz sonuçları nicelik olarak değerlendirildiğinde, ekonomik büyümede, sabit sermaye oluşumunda ve ekonomik küreselleşme düzeyinde meydana gelecek 1 birimlik artışın genç işsizliğinin sırasıyla 0.01 birim, 0.32 birim ve 0.008 birim azalmasına sebebiyet vereceğini göstermektedir.

Analiz sonuçları ekonomik büyüme açısından değerlendirildiğinde Okun Yasası'nı doğrular nitelikte olup, literatürde yer alan D'lppolito (2011), Güney ve Cin (2020), Soylu ve Aydın (2020) çalışma sonuçlarıyla örtüşmektedir. Ayrıca ekonomik küreselleşme açısından analiz sonuçlarının Awad (2019) ve Awad ve Youssof (2016) çalışma sonuçlarına örtüşmektedir.

\section{Sonuç ve değerlendirme}

İşsizlik konusu iktisat teorisinin başlangıcı kabul edilen Klasik iktisat döneminden günümüze kadar ekonomi literatürünü oldukça meşgul eden bir konu olmuştur. Nüfus planlaması dahil tüm ekonomik politikalarda ülkelerin önemle üzerinde durduğu işsizlik sosyal sonuçları açısından önem arz etmektedir. Dünya ekonomisinden küresel ekonomiye geçişle birlikte diğer ekonomik ve sosyo-kültürel politikalarda olduğu gibi işsizliği azaltma politikalarında da ülkeler arasında ortak uygulamalar gerçekleşmektedir. Genel itibariyle işsizlik sorunun çözümünde ihracat, ithalat, yatırımlar ve ekonomik büyümenin sağlanması gibi makro ekonomik faktörlerin kullanıldığı görülmektedir.

Ekonomik büyümenin işsizlik oranını azalttı̆̆ını öne süren Okun Yasası kapsamında ülkeler ekonomik büyümeyi gerçekleştirecek politikalar yoluyla işsizliği azaltma yoluna gitmektedir. Ekonomik, sosyal, kültürel ve siyasi boyutta ülkeler arasındaki engellerin kaldırılmasını ifade eden küresel ekonomi, sermayenin uluslararası hareketini sağlayarak istihdam düzeyini etkileyebilmektedir. Aynı şekilde 
işgücü özgürlüğünün düzeyi de işgücünün hareketliliğine izin vererek istihdam açısından önemli bir enstrüman kabul edilmektedir. Sosyal boyutunun ön planda olması nedeniyle gelişmiş ve gelişmekte ülke ayrımı gözetmeksizin genel işsizliğin ötesinde yer alan genç işsizliği küresel çapta sosyal bir sorundur. Kendine has özellikleri de mevcut olan bu işsizlik boyutunun çözümüne yönelik politikaların geliştirilmesi tüm dünya ülkeleri için önem arz etmektedir.

Ülkelerin uyguladığı politikalar ve düzenlemeler ışığında bu çalışmada ekonomik büyüme, ekonomik küreselleşme, işgücü özgürlüğü, sabit sermaye oluşumu ve ücret düzeyinin genç işsizliği üzerindeki etkisi araştırılmıştır. Dinamik panel veri analizi kapsamında GMM tahmincisinden yararlanılan çalışmada OECD üyesi 35 ülkenin 2005-2018 dönemine ait verileri kullanılmıştır. Analiz sonuçları Okun Yasası' nı doğrular nitelikte olup ekonomik büyümede meydana gelen artışın genç işsizliğini azalttığını göstermektedir. Aynı şekilde sabit sermaye oluşumundaki artış da genç işsizliğini azaltmaktadır. Sabit sermaye oluşumundaki artışın yeni yatırımlara dönüşerek yeni iş imkanları yarattığı söylenebilir. Ücret düzeyi ve işgücü özgürlüğü ile genç işsizliği arasında söz konusu dönemde istatistiksel olarak anlamlı bir ilişki tespit edilmemiştir. Son olarak analiz sonuçları ekonomik küreselleşmedeki artışın genç işsizliğini azalttığını göstermektedir. Bu sonuç, ilgili ülke grubu ve dönemde sermayenin uluslararası hareketi üzerindeki engellerin kaldırılma düzeyindeki artışın genç işsizliğini azalttığını ifade etmektedir.

Genç işsizliğin ekonomik sosyal sonuçları açısından oldukça önemli bir sorun olması ülkeleri ilave politikalar geliştirmeye itmektedir. Bu kapsamda değerlendirildiğinde politika yapıcıların başta ekonomik büyümeyi artırıcı para ve maliye politikalarını kullanmaları elzem görünmektedir. Gerek finansal gerekse reel piyasalarda uluslararası sermaye hareketliliğinin artırılmasına yönelik politikalar ve düzenlemeler hem imalat sanayii sektöründe genişlemeler yaratarak hem de finansman sağlayarak istihdam üzerinde pozitif etki sağlayacaktır. Son olarak sabit sermaye oluşumundaki artışın genç işsizliğini azaltması ile ilgili olarak, yeni yatırımların genç nüfusun eğitim ve donanımları çerçevesinde değerlendirilmesi genç işsizliğin nedenlerinden biri olarak görülen eğitim/donanım ile piyasadaki iş gücü talebinin niteliği arasındaki uyumsuzluğu ortadan kaldırabilecektir.

\section{Hakem Değerlendirmesi / Peer-review:}

Dış bağımsız

Externally peer-reviewed

\section{Çıkar Çatışması / Conflict of interests:}

Yazar(lar) çıkar çatışması bildirmemiştir.

The author(s) has (have) no conflict of interest to declare.

\section{Finansal Destek / Grant Support:}

Yazar bu çalışma için finansal destek almadığını beyan etmiştir.

The author declared that this study has received no financial support.

\section{Kaynakça / References}

Acedanski, J. (2016). Youth unemployment and welfare gains from eliminating business cycles - The case of Poland. Economic Modelling, 57, 248-262.

Akbulut Yıldız, G. (2020). Gelişmekte Olan Ülkelerde işçi Dövizlerinin Finansal Gelişme Üzerindeki Etkisi: Dinamik Panel Veri Analizi. Maliye Dergisi, 178, 98-114.

Arellano, M., ve Bond, S. (1991). Some Tests of Specification for Panel Data: Monte Carlo Evidence and an Application to Employment Equations. The Review of Economic Studies, 58(2), 277-297. 
Awad, A. (2019). Economic Globalisation and Youth Unemployment: Evidence from African Countries. International Economic Journal, 33(2), 252-269.

Balcı-İzgi, B. ve Konu, A. (2019). Genç İşsizliğini Belirleyen Unsurlar: BRICS Ülkeleri ile Türkiye Panel ARDL Uygulaması. Dokuz Eylül Üniversitesi Sosyal Bilimler Enstitüsü Dergisi, 21(1), 95-112.

Baltagi, B. (2005). Econometric Analysis of Panel Data. John Wiley \& Sons.

Caporale, G. M., \& Gil-Alana, L. (2014). Youth unemployment in Europe: persistence and macroeconomic determinants. CESifo Working Paper, 4696(4), 1-19.

Choudhry, M. T., Marelli, E. ve Signorelli, M. (2010). The Impact of Financial Crises on Youth Unemployment Rate. Quaderni del Dipartimentodi Economia, Finanza e Statistica, 79, 1-18.

D'lppolito, N. (2011), Youth Unemployment the Cases of Denmark and Italy, Department of Economics Copenhagen Business School, Number of UBS: 180279.

Güney, K. ve Cin, M.F. (2020). Avrupa Birliği ve Türkiye'de Genç İşsizliğinin Belirleyicileri: Panel Veri Analizi. ÇAKÜ Sosyal Bilimler Enstitüsü Dergisi, 11(1), 232-252.

Güvenoğlu, H. ve Bayır, M. (2020). Genç İşsizliği Etkileyen Faktörlere İlişkin Ampirik Bir Analiz. Uluslararası iktisadi ve idari bilimler dergisi, 6(2), 19-36.

Hallsten, M., Edling, C. ve Rydgren, J. (2017). Social capital, friendship networks, and youth unemployment. Social Science Research, 61, 234-250.

Kanberoğlu, Z. ve Göçer, M. (2019). Türkiye'de inovasyonun Genç İşsizlik Üzerindeki Etkisi. International Journal of Economics and Politics Sciences Academic Researches, 3(9), 61-78.

Kaslik, E., Neamtu, M. ve Vesa, L.F. (2021). Global stability analysis of an unemployment model with distributed delay. Mathematics and Computer in Simulation, 185, 535-546.

Okun, A. (1962). Potential GNP: Its Measurement and Significance. Proceedings of the Business and Economic Statistics Section of the American Statistical Association, 7(1), 89-104.

Polat, M. A. (2020). Ekonomik ve Politik Belirsizliklerin Yunanistan'daki Genç İşsizliğe Etkileri: Ampirik Bir Analiz. Yönetim ve Ekonomi Araştırmaları Dergisi, 18(2), 128-148.

Sam, S. O. (2015). Modelling economic determinants of youth unemployment in Kenya. Unpublished Postgraduate Thesis. University of Nairobi, Kenya.

Sertkaya, Y. ve Okur, A. (2016). Türkiye'de Genç İşsizliğinin Belirleyicilerine Yönelik Ekonometrik Bir Analiz. Ardahan Üniversitesi İktisadi ve İdari Bilimler Fakültesi Dergisi, 3, 155-168.

Soylu, B. ve Aydın, B. N. (2020). Genç İşsizliğin Gelişimi, Belirleyicileri ve İktisadi Politikalar: Avrupa Birliği-Türkiye Karşılaştırması. EKEV Akademi Dergisi, 24(82), 339-360.

Sönmez, F. D. ve Özerkek, Y. (2018). Türkiye'de Bölgesel Genç İşsizliğin Belirleyicileri. Marmara Üniversitesi İktisadi ve İdari Bilimler Dergisi, 40(2), 297-318.

Tatoğlu, F.Y. (2013). İleri Panel Veri Analizi: Stata Uygulamalı (2.bs.). İstanbul: Beta.

Üzar, U. ve Akyazı, H. (2018). Ekonomik Büyüme ve İşsizlik Arasındaki İlişkinin OECD Ülkeleri Düzeyinde Ekonometrik Bir Analizi. Cumhuriyet Üniversitesi İktisadi ve İdari Bilimler Dergisi, 19(2), 463-479.

Yıldız, G. (2019). OECD Ülkeleri ve Türkiye'de Genç İşsizlik-Büyüme İlişkisi Üzerine Bir İnceleme. Yayınlanmamış Yüksek Lisans Tezi. Bilecik Şeyh Edebali Üniversitesi/Sosyal Bilimler Enstitüsü, Bilecik. 